

\title{
The Effect of Metal Transfer Modes and Shielding Gas Composition on the Emission of Ultrafine Particles in MAG Steel Welding
}

\author{
(Efeito dos modos de transferência e da composição de gás de protecção na emissão de partículas ultrafinas na soldadura \\ MAG de aços)
}

\author{
J. F. Gomes ${ }^{1,2}$, R. M. Miranda ${ }^{3 *}$, P.A. Carvalho ${ }^{4}$, M. L. Quintino ${ }^{5}$ \\ ${ }^{1}$ CERENA - Centro de Recursos Naturais e Ambiente / Instituto Superior Técnico - Universidade de Lisboa, Av. Rovisco Pais, 1049- \\ 001 Lisboa, Portugal \\ ${ }^{2} I S E L$ - Instituto Superior de Engenharia de Lisboa, Área Departamental de Engenharia Química, R. Conselheiro Emídio Navarro, \\ 1959-007 Lisboa, Portugal \\ ${ }^{3}$ UNIDEMI, Departamento de Engenharia Mecânica e Industrial, Faculdade de Ciências e Tecnologia, FCT, Universidade Nova de \\ Lisboa, 2829-516 Caparica, Portugal \\ ${ }^{4}$ ICEMS, Departamento de Engenharia Química, Instituto Superior Técnico - Universidade de Lisboa, Av. Rovisco Pais, $1049-001$ \\ Lisboa, Portugal \\ ${ }^{5}$ Instituto Superior Técnico - Universidade de Lisboa, Av. Rovisco Pais, 1049-001 Lisboa, Portugal \\ *Corresponding author-Email:rmiranda@fct.unl.pt
}

Phone:+351.91.9848480

\begin{abstract}
Resumo
Este estudo consistiu na caracterização de partículas ultrafinas emitidas durante a soldadura de arco de aço ao carbono e inoxidável, utilizando diferentes misturas como protecção gasosa por forma a avaliar a influência dos modos de transferência, medidos pelos parâmetros operacionais e pela composição das misturas gasosas, na quantidade e na morfologia das partículas ultrafinas. Verificouse que a quantidade de partículas ultrafinas emitidas (medida como o número de partículas e como a área superficial das partículas depositadas ao nível dos alvéolos pulmonares) depende fortemente dos principais parâmetros de soldadura, em particular, da intensidade de corrente e da entrega térmica. A emissão de partículas ultrafinas aumenta com a intensidade de corrente, do mesmo modo que a emissão de fumos. Quando se comparam diferentes misturas de gases de protecção, observam-se maiores emissões para misturas mais oxidantes, ou seja, com maior teor de $\mathrm{CO}_{2}$, e maiores valores de áreas superficiais depositadas ao nível dos alvéolos pulmonares, o que origina situações mais gravosas em termos da exposição dos trabalhadores.
\end{abstract}

\section{Abstract}

The present study aims to characterize ultrafine particles emitted during gas metal arc welding of mild steel and stainless steel, using different shielding gas mixtures, and to evaluate the effect of metal transfer modes, controlled by both processing parameters and shielding gas composition, on the quantity and morphology of the ultrafine particles. It was found that the amount of emitted ultrafine particles (measured by particle number and alveolar deposited surface area) are clearly dependent from the main welding parameters, namely the current intensity and the heat input of the welding process. The emission of airborne ultrafine particles increases with the current intensity as fume formation rate does. When comparing the shielding gas mixtures, higher emissions were observed for more oxidizing mixtures, that is, with higher $\mathrm{CO}_{2}$ content, which means that these mixtures originate higher concentrations of ultrafine particles (as measured by number of particles by cubic centimeter of air) and higher values of alveolar deposited surface area of particles, thus resulting in a more hazardous condition regarding welders exposure.

Keywords: gas metal arc welding; welding fumes; ultrafine particles; alveolar deposited surface area.

\section{Introduction}

Gas metal arc welding is extensively used in metallic construction worldwide.

Recebido em 24/03/2014, texto final em 16/07/2014.

DOI: 10.1590/0104-9224/SI1902.09
It is well known that welders are exposed to significant amounts of welding fumes produced, which depend on process parameters and shielding gas composition [1]. Previous works [2] showed a correlation between processing parameters in metal active gas (MAG), that is, metal transfer modes, and the quantity of fumes formed expressed by the fume formation rate. Additionally, the gas mixtures have also an influence on the fumes (quantity and composition), since the higher the oxygen 
contents of the gas, the higher the fume formation rate observed. With the advent of new types of welding procedures and consumables, the number of welders exposed to welding fumes is continuously growing, in spite of the mechanization and automation of the welding processes [3] and individual welders' protection equipment is improving. The number of epidemiologic studies [4] has increased in recent years due to the increasing concern with welding fumes and more sophisticated equipment for ultrafine particle (UFP) detection and analysis. The influence of ultrafine particulate lying in the nano sized range, on human health has been pointed to be of much concern [5] as airborne ultrafine particles can also result from macroscopic common industrial processes such as welding [6]. The detrimental health effects of inhaling ultrafine aerosols were recognised long ago and various attempts have been made to minimise exposure, as the issuing of specific regulations on emissions and objectives for air quality in working microenvironments [7].

When considering human exposure to airborne pollutants the exposure to airborne particles, and specifically to its finer fractions, such as sub micrometer particles, is of particular interest. Current workplace exposure limits, that have been established long ago, are based on particle mass, but this criteria may be not completely adequate for nano sized particles as these are characterized by very large surface areas (considering the same volume, nano sized particles have larger surface areas than micro sized particles), which has been pointed out as the distinctive characteristic that could even turn an inert substance into a toxic one, having the same chemical composition, and exhibiting very different interactions with biological fluids and cells [8]. As a result, assessing workplace conditions and personal exposure based on the measurement of particle surface area is of increasing interest. It is well known that lung deposition is the most efficient way for airborne particles to enter the body and potentially cause adverse health effects. If ultrafine particles can deposit in the lung and remain there with an active surface chemistry and interact with the body, then, there is potential for exposure and dosing. Oberdörster [9] showed that surface area plays an important role in the toxicity of nanoparticles and is the measurement metric that best correlates with particle-induced adverse health effects. Therefore, in order to be able to assess exposure, it is important to have an estimation of the surface area of emitted ultrafine particles, as they are potentially able to deposit in the lower parts of the lung, such as the alveoli and clog them, or even being transferred to the blood circulation system with resulting distribution in several end organs [10].

For industrial hygiene applications, American Conference of Government Industrial Hygienists (ACGIH) [11] developed a definition of a reference worker, in order to derive the corresponding deposition curves for tracheobronchial and alveolar lung deposition, based on the International Commission for Radiation Protection (ICRP) model: the tracheobronchial deposition curve represents the fraction of aerosol that deposits in the tracheobronchial region of the lung, while the alveolar deposition curve represents the fraction of the aerosol that deposits in the alveolar region of the lung. For exposure assessment applications, it is common to sample aerosols relevant to their deposition in a specific region of the human lung thus depending on the aerosol being sampled. In what concerns ultrafine particles, due to its very fine dimensions, the health effects would be related to the deposition deep in the alveolar regions of the lung, so the respirable fraction of the aerosol is the metric of interest, as it is interesting to assess the potential surface of the alveoli to be clogged by the presence of these ultrafine particles.

This work comes in line with preliminary work from these authors that demonstrated the presence of ultrafine particles in welding processes such as metal-active gas (MAG) [12], and aims to assess the emissions of ultrafine particles emitted from welding mild steel and stainless steel, and try to correlate these with operational parameters, including shielding gas mixtures composition and, thus, with molten metal transfer modes. Similar studies have also been done for welding fumes generated in other processes, such as manual metal arc welding (MMA) and tungsten inert gas welding (TIG) [13]. However, these did not address the deposited surface area of emitted particles. Additionally, there is no work correlating the effect of gas mixtures and molten metal transfer modes with the quantity and morphology of ultrafine particles emitted in MAG welding, which could be quite interesting to select operating conditions in order to obtain cleaner processes.

\section{Materials and methods}

MAG welding tests were performed in laboratory using an experimental set-up consisting of a commercial automatically controlled welding system using synergic mode, which assured

Table 1.Nominal chemical composition of the base materials under study (wt. \%)

\begin{tabular}{|l|c|c|c|c|c|c|c|c|}
\hline Steel & $\mathrm{C}$ & $\mathrm{Mn}$ & $\mathrm{P}$ & $\mathrm{S}$ & $\mathrm{Si}$ & $\mathrm{Ni}$ & $\mathrm{Cr}$ & $\mathrm{N}$ \\
\hline AISI1020 & 0.017 & 1.40 & 0.035 & 0.035 & - & - & - & - \\
\hline AISI304 & 0.08 & 2.0 & 0.045 & 0.030 & 0.75 & $8.0-10.5$ & $18-20.0$ & 0.10 \\
\hline
\end{tabular}

Welding consumables used were solid wires AWS 5.18 ER79S-6, with a diameter of $1 \mathrm{~mm}$ for mild steel and AWS ER316 LSi, with a diameter of $0.8 \mathrm{~mm}$, for stainless steel. Wire compositions are shown in table 2 .

Table 2. Nominal chemical composition of the solid wire used (wt. \%)

\begin{tabular}{|l|c|c|c|c|c|c|c|c|c|}
\hline Wire & $\mathrm{C}$ & $\mathrm{Mn}$ & $\mathrm{P}$ & $\mathrm{S}$ & $\mathrm{Si}$ & $\mathrm{Ni}$ & $\mathrm{Cr}$ & $\mathrm{Cu}$ & $\mathrm{Mo}$ \\
\hline AWS 5.18 ER70S-6 & $0.06-0.15$ & - & & 0.35 & $0.8-1.15$ & 0.15 & 0.15 & 0.50 & 0.15 \\
\hline AWS A5.9 ER316 LSi & 0.03 & $1.0-2.5$ & 0.03 & 0.03 & $0.65-1.00$ & $11-14$ & $18-20$ & 0.75 & $2.0-3.0$ \\
\hline
\end{tabular}


a stable electric arc, a constant welding speed and, therefore, repeatability of the welding process.

Bead on plate welds were performed on $3 \mathrm{~mm}$ thick mild steel plates of AISI 1020 with the chemical composition shown in table 1. Tests were also performed on $10 \mathrm{~mm}$ thick austenitic stainless steel plates in AISI 304 with the chemical composition also depicted in table 1.

The operating parameters used are depicted in tables 3 and 4 for mild steel and stainless steel, respectively, and were obtained with calibrated acquisition equipment. Different welding parameters were tested, varying the gas shielding mixture, the current intensity and the voltage in order to produce shortcircuit, globular and spray metal transfer modes. The welding voltage was adjusted automatically by the welding equipment in accordance with the wire feeding rate. Each condition tested was replicated twice in order to confirm measurements. Between each test, time intervals were considered in order to allow for dissipation of aerosol in the atmosphere of the sampling location, until the recuperation of baseline values takes place.

Gas protection was selected amongst the most frequently used gas mixtures, and these were:

- for mild steel: 100\% $\mathrm{CO}_{2} ; \mathrm{Ar}+10 \% \mathrm{CO}_{2}$ and $\mathrm{Ar}+18 \% \mathrm{CO}_{2}$;

- for stainless steel: $\mathrm{Ar}+5 \% \mathrm{CO}_{2} ; \mathrm{Ar}+18 \% \mathrm{He}+1 \% \mathrm{CO}_{2}$ and $\mathrm{Ar}+5 \% \mathrm{He}+2 \% \mathrm{CO}_{2}+2 \% \mathrm{~N}_{2}$.

Measurements were performed at a constant distance from the arc welding site as depicted in figure 1.

Table 3. Experimental test conditions for mild steel gas metal arc welding

\begin{tabular}{|c|c|c|c|}
\hline Gas mixture & \multicolumn{3}{|c|}{$\mathrm{Ar}+10 \% \mathrm{CO}_{2}$} \\
\hline Test nr. & 1 & 2 & 3 \\
\hline Wire feed rate $(\mathrm{m} / \mathrm{min})$ & 4.0 & 6.3 & 11.2 \\
\hline Intensity (A) & 102 & 137 & 194 \\
\hline Voltage $(\mathrm{V})$ & 17.8 & 20.0 & 32.4 \\
\hline Metal transfer mode & Short-circuit & Globular & Spray \\
\hline Gas mixture & \multicolumn{3}{|c|}{$\mathrm{Ar}+18 \% \mathrm{CO}_{2}$} \\
\hline Test nr. & 1 & 2 & 3 \\
\hline Wire feed rate $(\mathrm{m} / \mathrm{min})$ & 4.0 & 6.3 & Not attained \\
\hline Intensity (A) & 92 & 122 & - \\
\hline Voltage $(\mathrm{V})$ & 17.7 & 19.9 & - \\
\hline Metal transfer mode & Short-circuit & Globular & Spray \\
\hline Gas mixture & \multicolumn{3}{|c|}{$\mathrm{CO}_{2}$} \\
\hline Test nr. & 1 & 2 & 3 \\
\hline Wire feed rate $(\mathrm{m} / \mathrm{min})$ & 5.0 & 7.5 & Not attained \\
\hline Intensity (A) & 64 & 129 & - \\
\hline Voltage $(\mathrm{V})$ & 18.7 & 21.1 & - \\
\hline Metal transfer mode & Short-circuit & Globular & Spray \\
\hline
\end{tabular}

Table 4. Experimental test conditions for stainless steel gas metal arc welding

\begin{tabular}{|l|c|c|c|}
\hline Gas mixture & \multicolumn{3}{|c|}{$\mathrm{Ar}+5 \% \mathrm{CO}_{2}$} \\
\hline Test nr. & 1 & 2 & 3 \\
\hline Wire feed rate (m/min) & 5.0 & 7.0 & 9.0 \\
\hline Intensity (A) & 92 & 182 & 211 \\
\hline Voltage (V) & 18.9 & 25.0 & 30.2 \\
\hline Transfer mode & Short-circuit & Globular & Spray \\
\hline Gas mixture & \multicolumn{3}{|c|}{$\mathrm{Ar}+18 \% \mathrm{He}+1 \% \mathrm{CO}_{2}$} \\
\hline Test nr. & 1 & 2 & 3 \\
\hline Wire feed rate (m/min) & 5.0 & 7.0 & 199 \\
\hline Intensity (A) & 133 & 171 & 29.9 \\
\hline Voltage (V) & 18.8 & 25.0 & Spray \\
\hline Transfer mode & Short-circuit & $\mathrm{Globular}$ & 3 \\
\hline Gas mixture & \multicolumn{3}{|c|}{$\mathrm{Ar}+5 \% \mathrm{He}+2 \% \mathrm{CO}_{2}+2 \% \mathrm{~N}_{2}$} \\
\hline Test nr. & 1 & 2 & 9.8 \\
\hline Wire feed rate (m/min) & 6.0 & 7.0 & 226 \\
\hline Intensity (A) & 109 & 185 & 30.8 \\
\hline Voltage (V) & 19.1 & 25.2 & Spray \\
\hline Transfer mode & Short-circuit & Globular & \\
\hline
\end{tabular}




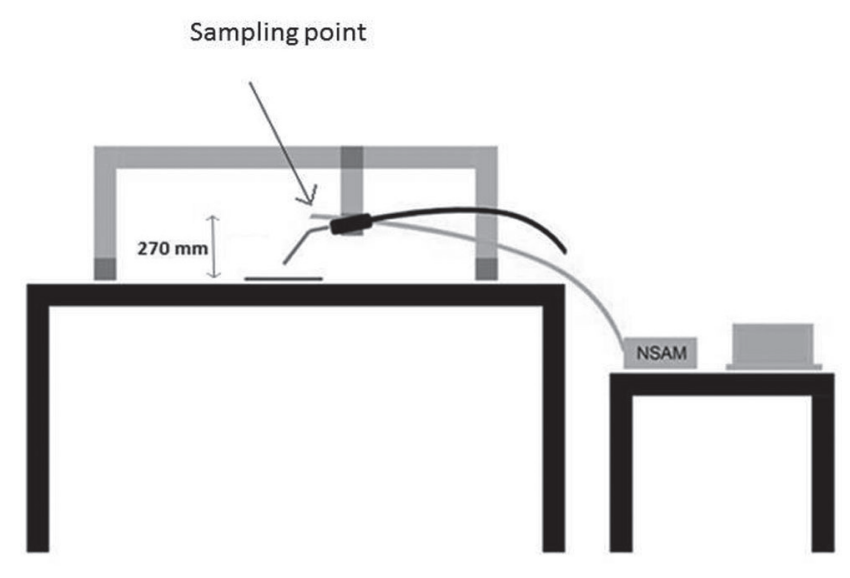

Figure 1. Location of the sampling point

For measuring ultrafine particle (diameter lower than $1 \mathrm{~nm}$ ) exposure a Nanoparticle Surface Area Monitor (NSAM), TSI, Model 3550, was used. This equipment indicates the human lung-deposited surface area of particles (ADSA) expressed as square micrometers per cubic centimeter of air $\left(\mu \mathrm{m}^{2} /\right.$ $\mathrm{cm}^{3}$ ), corresponding to the alveolar region of the lung [4, 12], measuring each 10 seconds. This equipment is based on diffusion charging of sampled particles, followed by detection of the charged aerosol using an electrometer. Using an integral pump, an aerosol sample is drawn into the instrument through a cyclone with a $1 \mu \mathrm{m}$ cut point. The sample flow is split, with one stream going through a set of carbon and HEPA filters and an ionizer to introduce positively charged ions into a mixing chamber. The other aerosol flow stream is mixed with the ionized stream in a mixing chamber and charged aerosol and excess ions move onto an ion trap which can be set to alveolar response. The ion trap acts as an inlet conditioner or a size-selective sampler for the electrometer, by collecting the excess ions and particles that are not of a charge state, corresponding to the response settings. The aerosol, then moves on to the electrometer for charge measurement, where current is passed from the particles to a conductive filter and measured by a very sensitive amplifier. The charge measured by the electrometer is directly proportional to the surface area of the particles passing through the electrometer. The equipment matches the corresponding lung deposition criteria of particles for a reference worker predicted by human lung deposition models from ICRP and ACGIH [11].

Due to the inexistence of an exposure limit value specific for ultrafine particles, a baseline value was measured, before each welding test, for comparison purposes.

Particles were also collected using a Nanometer Aerosol Sampler (NAS), TSI, Model 3089, on $3 \mathrm{~mm}$ diameter copper grids polymer coated for further observation by transmission electron microscopy (TEM). The microscope was a Hitachi, model H-8100, equipped with an energy dispersive X-ray spectroscopy (EDS) probe.

\section{Results and discussion}

It is well known that molten metal transfer modes are controlled by different forces responsible for the droplet size and type of detachement, as well as on spatter and fume formation.

Pires et al.[1] concluded that the fume formation rate was low for short circuit transfer mode and increased for globular and spray transfer modes. This was intrinsically related to the acting forces on the arc, which are described by the static force balance theory [14] and the pinch instability theory [15]. The fume formation rate was seen to increase with the arc temperature and instability, the droplets size and the content of the active component on the shileding gas mixture, increasing for $\mathrm{CO}_{2}$ or $\mathrm{O}_{2}$, more specifically with the thermal conductivity of the gas. Since $\mathrm{CO}_{2}$ has a high thermal conductivity it leads to high fume formation rate [1]. In fact, Pires [16] observed that, as the thermal conductivity of the $\mathrm{CO}_{2}$ rich gas mixtures increases, the arc stops enveloping the droplet, producing an anodic spot contraction, resulting in a shorter electric conduction zone. For mixtures with low quantities of $\mathrm{CO}_{2}$, the opposite is verified.

In mild steel, the use of $\mathrm{CO}_{2}$ allows for deep penetration welds, but forms oxide formation which has a detrimental effect in welds. So, additions of Argon are used to prevent this. The arc stability decreases with the increase of $\mathrm{CO}_{2}$ content in the binary mixture of $\mathrm{CO}_{2}+\mathrm{Ar}$ when welding mild steel. This is due to the higher thermal conductivity of $\mathrm{CO}_{2}$ which increases heat losses by conduction and thus arc instability for a constant current intensity [1]. In short circuit MAG, increasing the $\mathrm{CO}_{2}$ content increases the weld heat and introduced heat increases the penetration.

Analysing the measured alveolar deposited surface area (ADSA) for mild steel, it can be seen that ADSA increases with the welding current intensity. For the binary gas mixture of $\mathrm{Ar}+10 \% \mathrm{CO}_{2}, \mathrm{ADSA}$ values are higher for spray and the lowest was measured for short circuit transfer mode, as shown in figures 2 and 3. It should be noted that these graphs show the integrated curves for the whole welding period, which means that the graphs show the acumulated ADSA for the whole welding test, which lasted between 30 and and 90 seconds.

For more oxidizing mixtures, as $\mathrm{Ar}+18 \% \mathrm{CO}_{2}$, and $\mathrm{CO}_{2}$, it was not possible to measure the alveolar deposited surface area in spray metal transfer mode since the values were above the equipment upper limit, so just ADSA values for globular and short circuit modes were registered, as shown in figure 4.

Analysing data for globular transfer mode in mild steel, all shielding gas mixtures tested lead to higher values than in short circuit transfer mode, and the maximum value was observed for $\mathrm{CO}_{2}$, as shown in figures 5 and 6 .

In fact, short circuit metal transfer mode is obtained for low current intensities and voltages. Consequently, the arc power (I $\mathrm{x} U$ ) decreases and the internal heat also decreases. This mode is seen to produce less spatter than globular transfer [1, 17]. Additionally, the arc is short and the opening time, within a weld cycle is small. Globular metal transfer is achieved for high current intensity and voltage, thus the arc power is high and this is adopted for high deposition rates in flat and horizontal position due to the less controlled droplet detachment [15]. Is is a cost effective way to weld mild steel, specially using $\mathrm{CO}_{2}$ despite the high spatter produced.

The fact that in spray transfer mode droplet detachment is 
more controllable with no spatter makes it adequate for high deposition rates in flat position and vertical down welds. It is seen not to produced spatter, despite the large amount of ultrafine particles measured (the arc power is even higher).

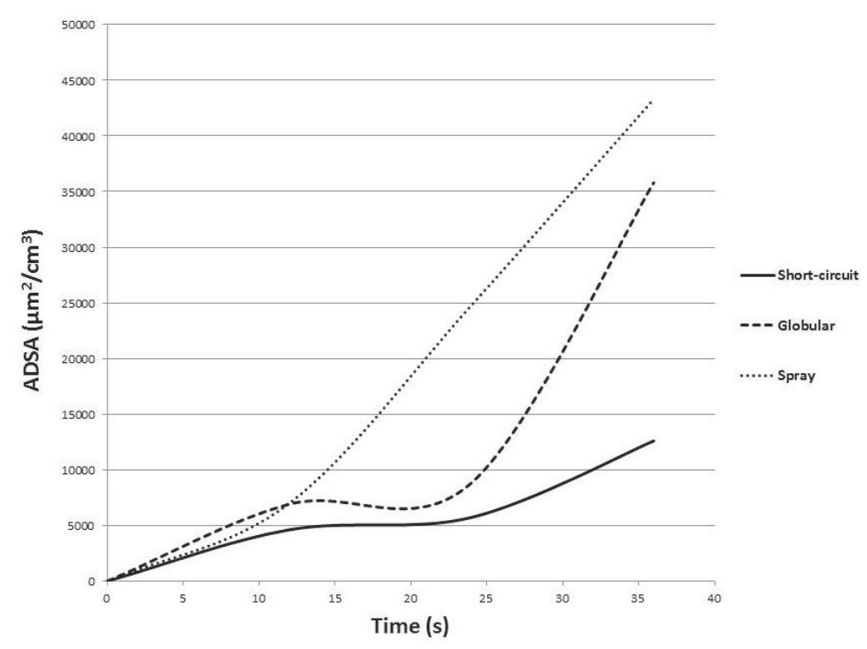

Figure 2. Results for welding tests with $\mathrm{Ar}+10 \% \mathrm{CO}_{2}$ : mild steel

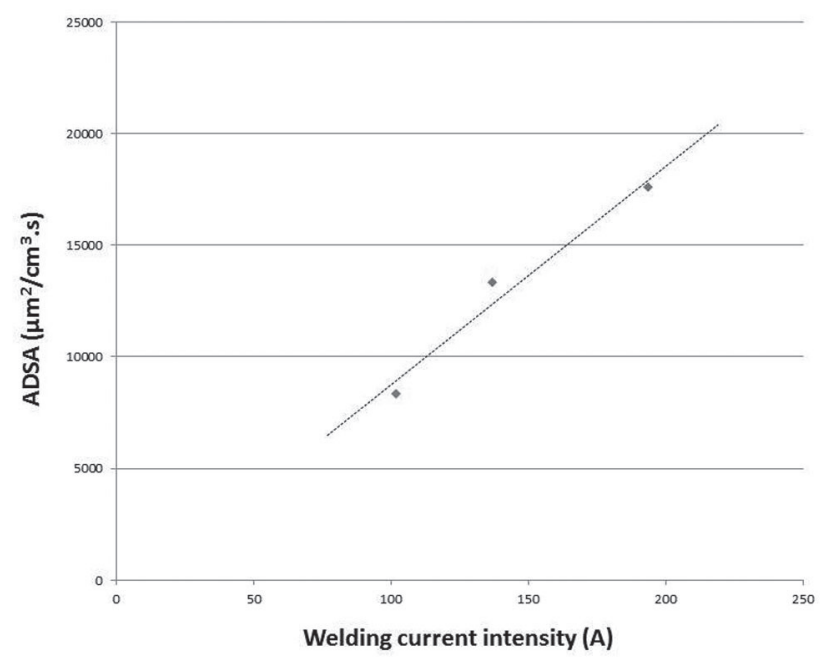

Figure 3. Variation of ADSA with welding current intensity for $\mathrm{Ar}+10 \% \mathrm{CO} 2$ : mild steel

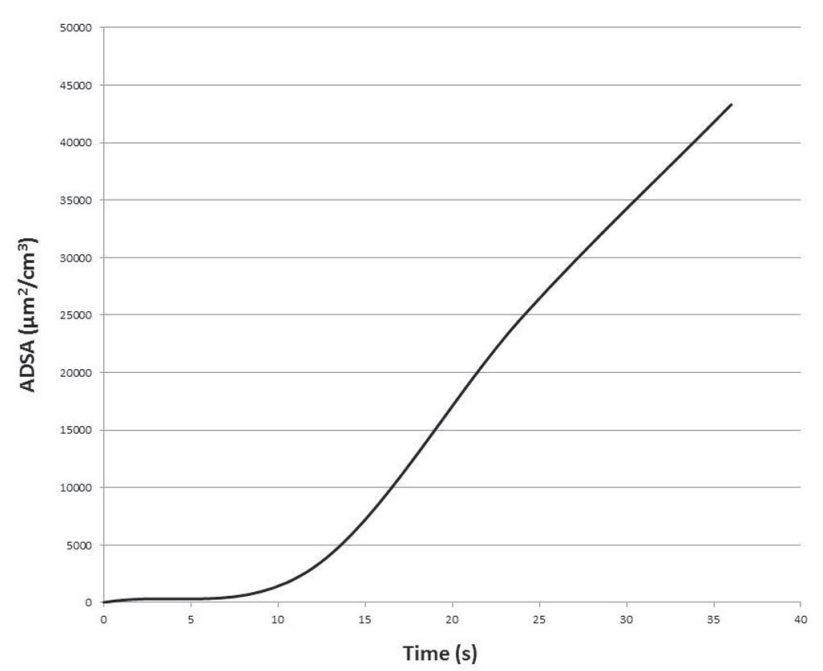

Figure 4. Results for welding tests with mild steel: spray transfer mode

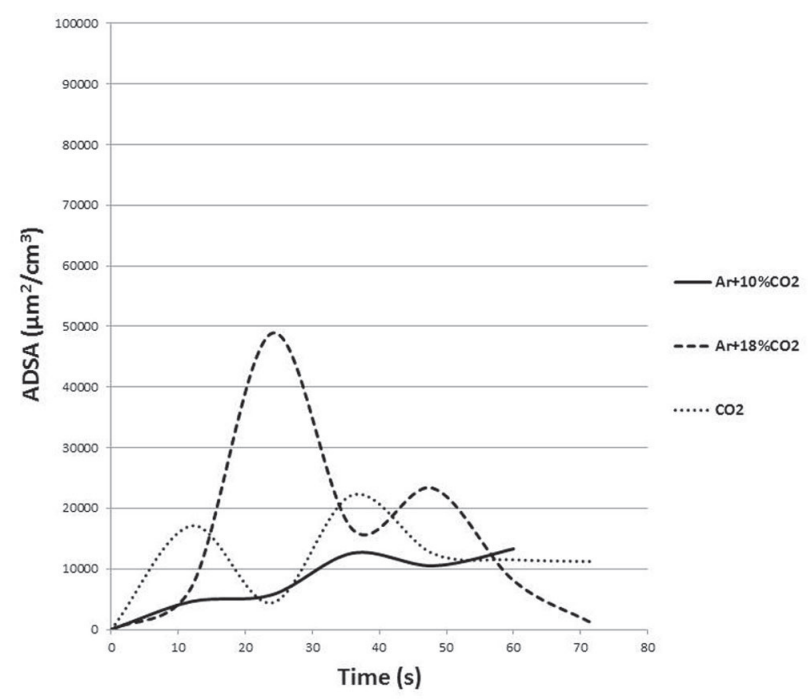

Figure 5. Results for welding tests with mild steel: short-circuit transfer mode

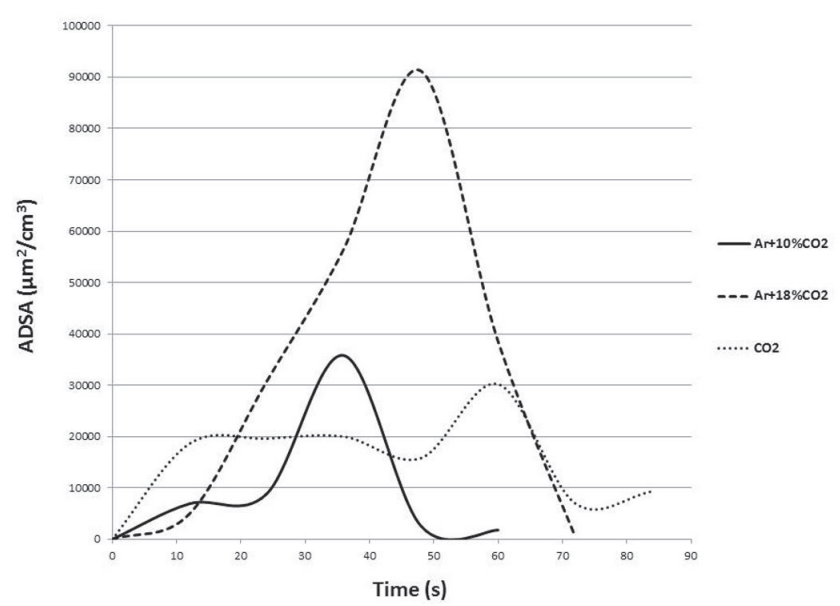

Figure 6. Results for welding tests with mild steel: globular transfer mode 


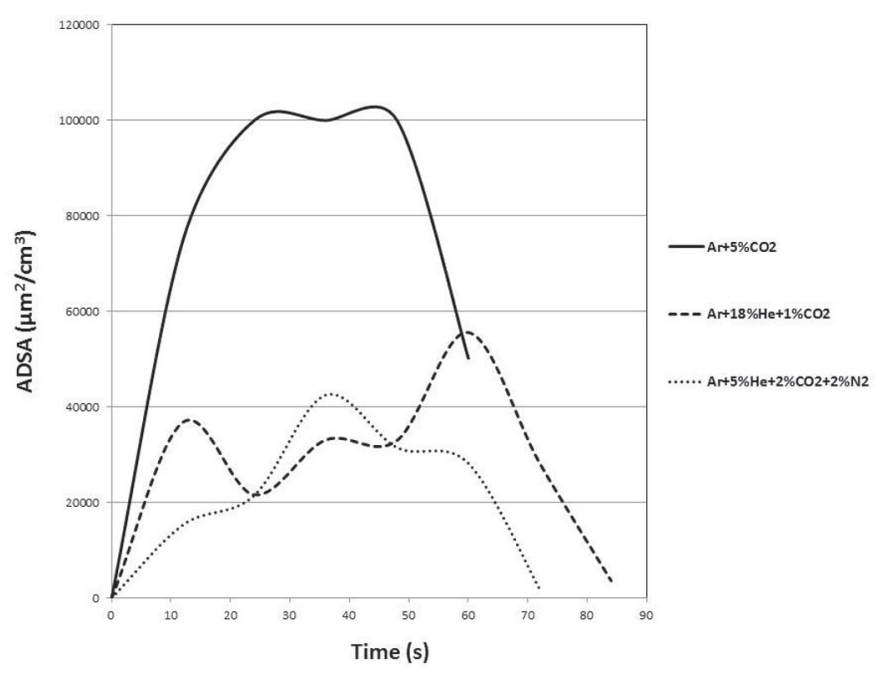

Figure 7. Results for welding tests with stainless steel: shortcircuit transfer mode

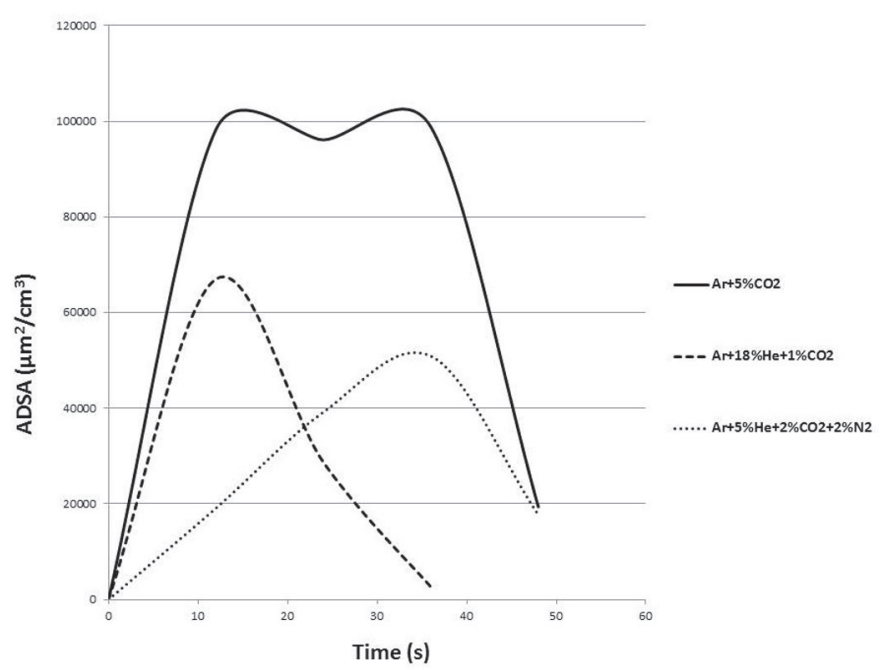

Figure 8. Results for welding tests with stainless steel: globular transfer mode

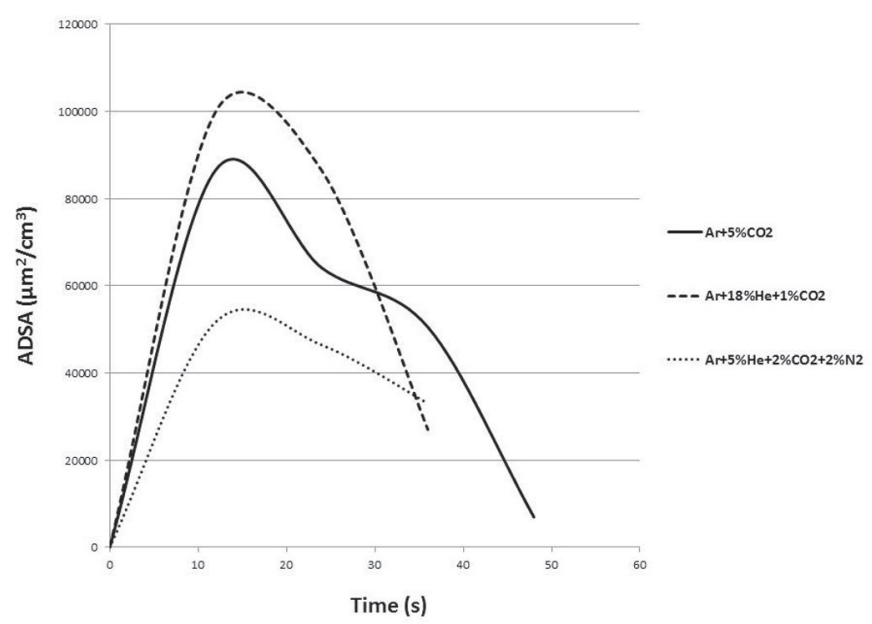

Figure 9. Results for welding tests with stainless steel: spray transfer mode

It can be seen that both the gas mixture and the transfer modes have a marked influence on the nanoparticulate emissions. Table 5 shows the average ADSA values obtained for the welding tests in mild steel, where the highest values are underlined. Using the gas mixture $\mathrm{Ar}+10 \% \mathrm{CO}_{2}$, spray transfer mode is the one that results in higher ADSA values, and the same occurs for the other gas mixtures. Increasing the values of the welding parameter under test values, increase the ADSA values. One could expect the highest ADSA values were obtained for $100 \%$ $\mathrm{CO}_{2}$ : however, this behaviour was not obtained for this mixture but for $\mathrm{Ar}+18 \% \mathrm{CO}_{2}$. Using $\mathrm{Ar}+18 \% \mathrm{CO}_{2}$ the highest ADSA values were obtained in the short-circuit transfer mode, instead of spray mode, which corresponds to higher current intensities.

Table 5. Average ADSA values obtained during welding tests for mild steel

\begin{tabular}{|l|c|c|c|}
\hline \multirow{2}{*}{$\begin{array}{l}\text { Gas mixture } \\
\text { Metal transfer mode }\end{array}$} & \multicolumn{3}{|c|}{ Average ADSA $\left(\mu \mathrm{m}^{2} / \mathrm{cm}^{3} . \mathrm{s}\right)$} \\
\cline { 2 - 4 } & $\mathrm{Ar}+10 \% \mathrm{CO}_{2}$ & $\mathrm{Ar}+18 \% \mathrm{CO}_{2}$ & $100 \% \mathrm{CO}_{2}$ \\
\hline Short-circuit & 8325 & $\underline{22266}$ & 12899 \\
\hline Globular & 13306 & $\underline{42896}$ & 18292 \\
\hline Spray & $\underline{17574}$ & - & - \\
\hline
\end{tabular}

Table 6. Average ADSA values obtained during welding tests for stainless steel

\begin{tabular}{|l|c|c|c|}
\hline \multirow{2}{*}{$\begin{array}{l}\text { Gas mixture } \\
\text { Metal transfer mode }\end{array}$} & \multicolumn{3}{|c|}{ Average ADSA $\left(\mu \mathrm{m}^{2} / \mathrm{cm}^{3} . \mathrm{s}\right)$} \\
\cline { 2 - 4 } & $\mathrm{Ar}+5 \% \mathrm{CO}_{2}$ & $\mathrm{Ar}+18 \% \mathrm{He}+1 \% \mathrm{CO}_{2}$ & $\mathrm{Ar}+5 \% \mathrm{He}+2 \% \mathrm{CO}_{2}+2 \% \mathrm{~N}_{2}$ \\
\hline Short-circuit & 23637 & $\underline{75390}$ & 33644 \\
\hline Globular & 37054 & $\underline{94136}$ & 78361 \\
\hline Spray & 39376 & 65829 & $\underline{80861}$ \\
\hline
\end{tabular}


Figures 7-9 show, also the evolution of ADSA for the tested gas mixtures and obtained transfer modes (referenced on table 4), but for stainless steel welding, whereas table 6 shows the average ADSA values obtained, and, again the highest values are underlined.. Similarly to mild steel, ADSA values increase with the current intensity, except for $81 \% \mathrm{Ar}+18 \% \mathrm{He}+1 \% \mathrm{CO}_{2}$, which was expected, considering that the spray mode results in higher values than those with globular transfer mode.

In fact, $81 \% \mathrm{Ar}+18 \% \mathrm{He}+1 \% \mathrm{CO}_{2}$ is the gaseous mixture resulting in higher nanoparticles emissions, as measured by ADSA. A possible cause for this is related with the high content of $\mathrm{He}$ in the gaseous mixture (18\%). He exhibits a very high ionization energy value of $24.58 \mathrm{eV}$, this will result in an electric arc with higher temperatures, volatilizing elements from the base material and the consumable. Comparing tables $\mathrm{E}$ and $\mathrm{F}$, it is also possible to note that higher ADSA values are obtained for welding stainless steel than for mild steel.

Figures 10 to 12 show the collected nanoparticles observed under TEM. Figure 10 refers to welding mild steel with $\mathrm{Ar}+10 \% \mathrm{CO}_{2}$ and figures 11 and 12 to welding stainless steel
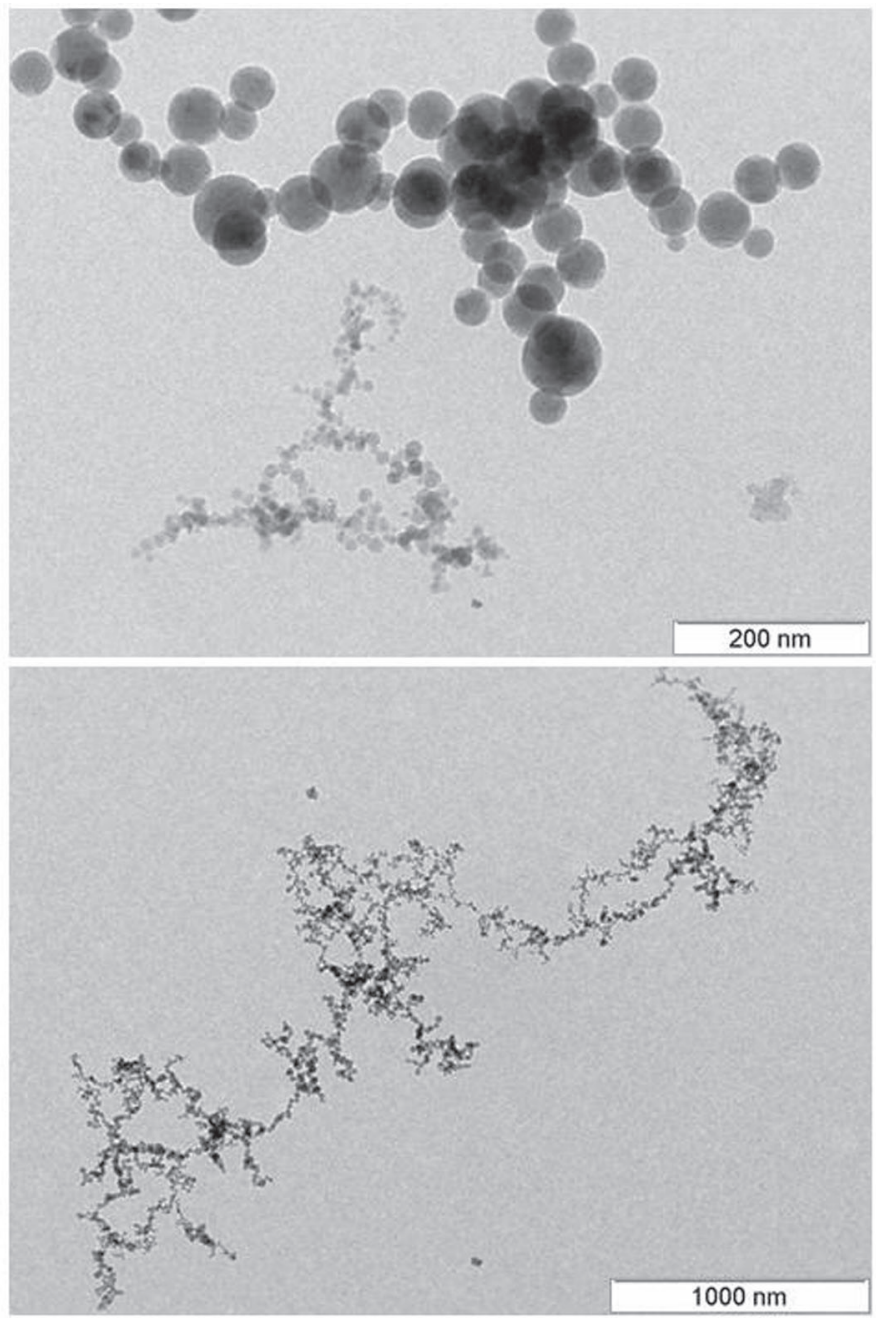

Figure 10. TEM image for nanoparticles collected for welding with $\mathrm{Ar}+10 \% \mathrm{CO}_{2}$ : mild steel -

a) top: indicative ruler $=200 \mathrm{~nm}$; b) bottom: indicative ruler $=1000 \mathrm{~nm}$ with $\mathrm{Ar}+18 \% \mathrm{He}+1 \% \mathrm{CO}_{2}$ and $\mathrm{Ar}+5 \% \mathrm{He}+2 \% \mathrm{CO}_{2}+2 \% \mathrm{~N}_{2}$, respectively. Nanoparticles shown in figures 10 are spherical, amorfous and with dimensions ranging from 10 to $90 \mathrm{~nm}$, and are present in the form of small aggregates together. Similarly, nanoparticles colected during stainless steel welding are spherical and amorfous, agglomerated, with dimensions ranging from 10 to $40 \mathrm{~nm}$, smaller than in mild steel.
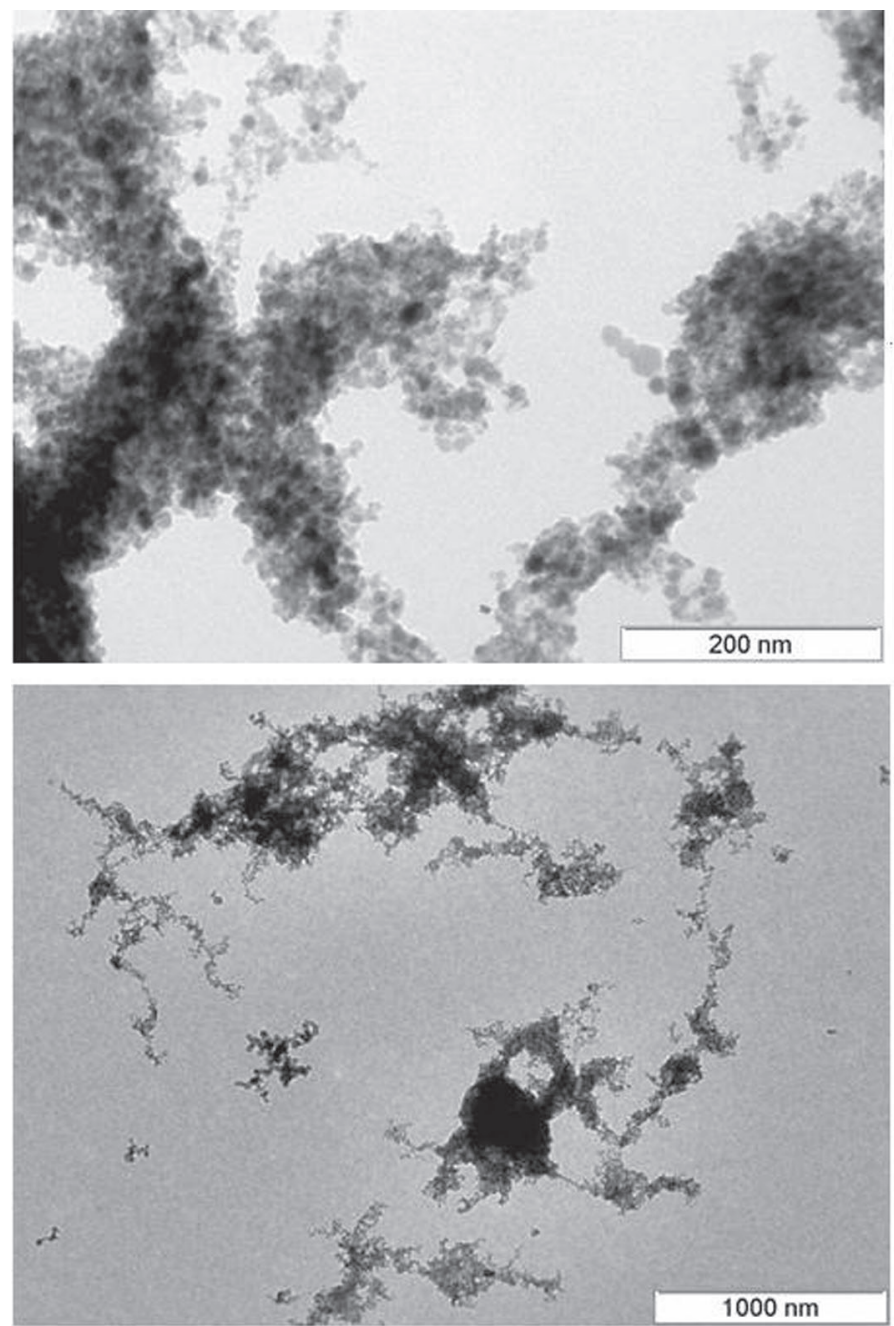

Figure 11. TEM image for nanoparticles collected for welding with $81 \% \mathrm{Ar}+18 \% \mathrm{He}+1 \% \mathrm{CO}_{2}$ : stainless steel - a) top: indicative ruler $=200 \mathrm{~nm}$; b) bottom: indicative ruler $=1000 \mathrm{~nm}$

The particles were subjected to chemical analysis, by EDS, and the obtained spectra are shown in figures 13 and 14, for mild steel $\left(\mathrm{Ar}+10 \% \mathrm{CO}_{2}\right)$ and for stainless steel $\left(\mathrm{Ar}+5 \% \mathrm{He}+2 \% \mathrm{CO}_{2}+2 \% \mathrm{~N}_{2}\right)$, respectively. Regarding mild steel, the elements detected were iron, silicium and manganese (copper is also shown in the spectra but it is due to the grids used for collecting nanoparticles). For stainless steel, the detected elements were iron, cromium and nickel, which confirms the origin both from the base material and the consumable which are potentially carcinogenic elements. 


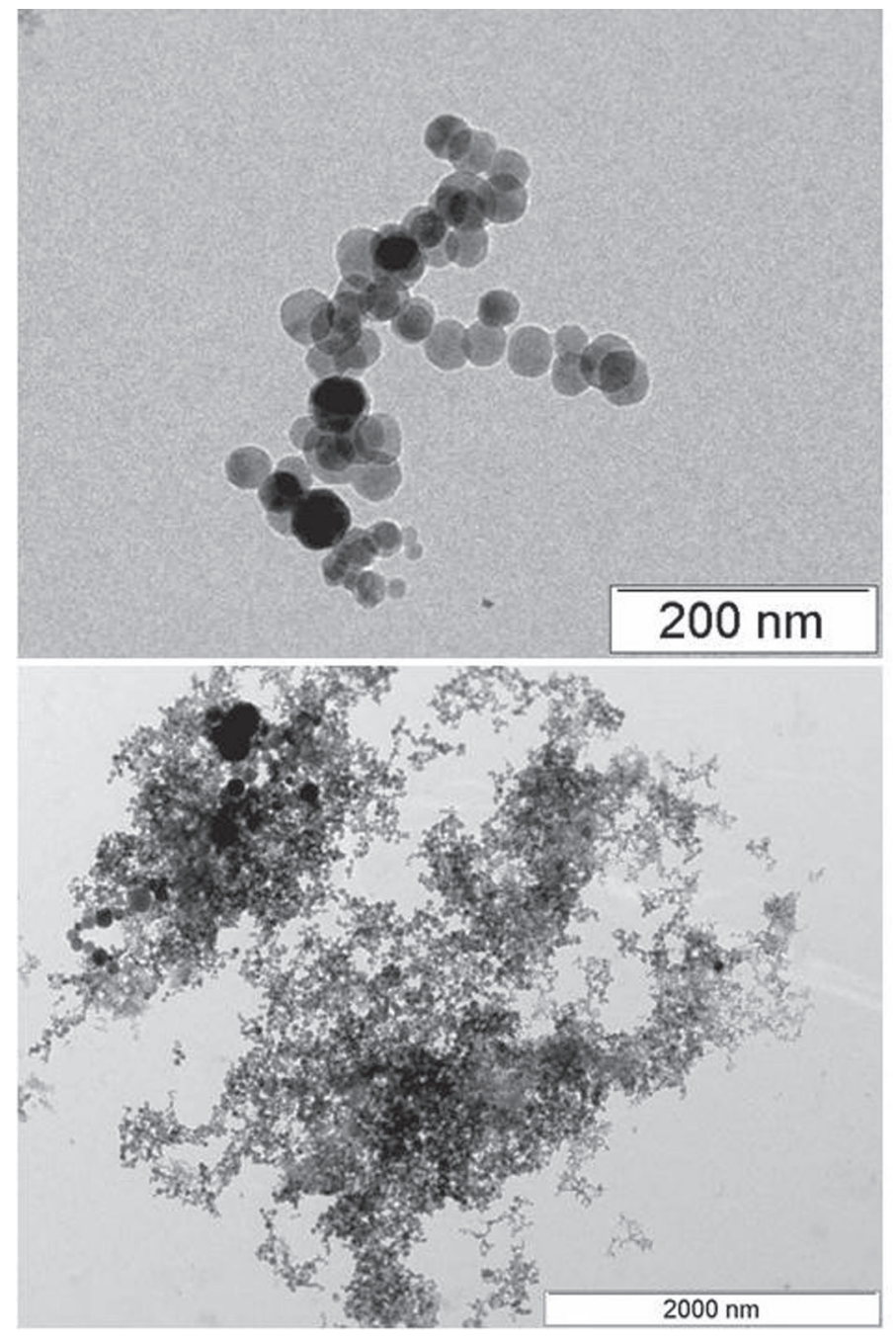

Figure 12. TEM image for nanoparticles collected for welding with $91 \% \mathrm{Ar}+5 \% \mathrm{He}+2 \% \mathrm{CO}_{2}+2 \% \mathrm{~N}_{2}$ : stainless steel - a) top: indicative ruler $=200 \mathrm{~nm}$; b) bottom: indicative ruler $=2000 \mathrm{~nm}$

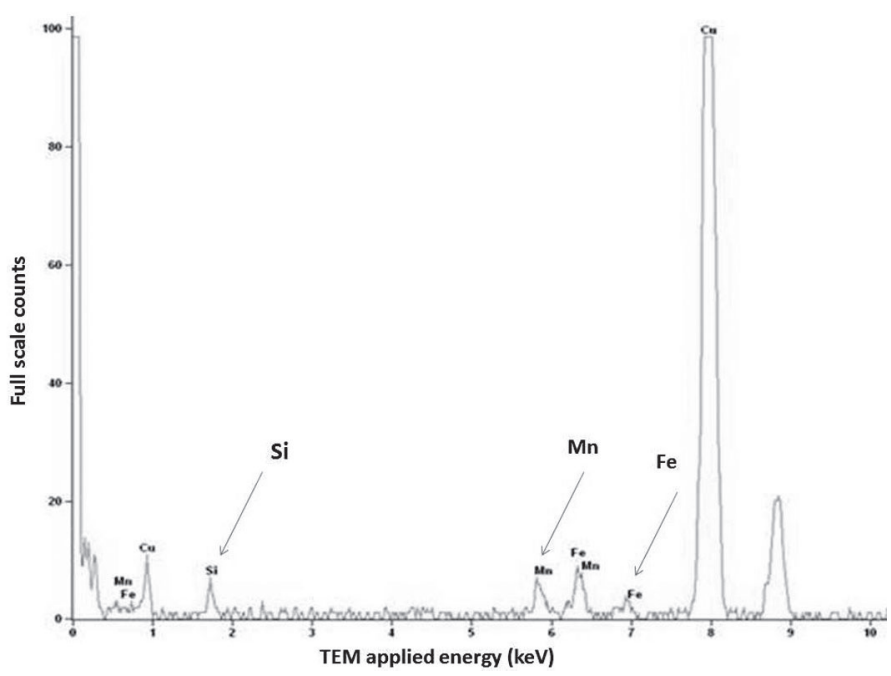

Figure 13. EDS spectra showing chemical composition of nanoparticles collected for welding with $\mathrm{Ar}+10 \% \mathrm{CO}_{2}$ : mild steel

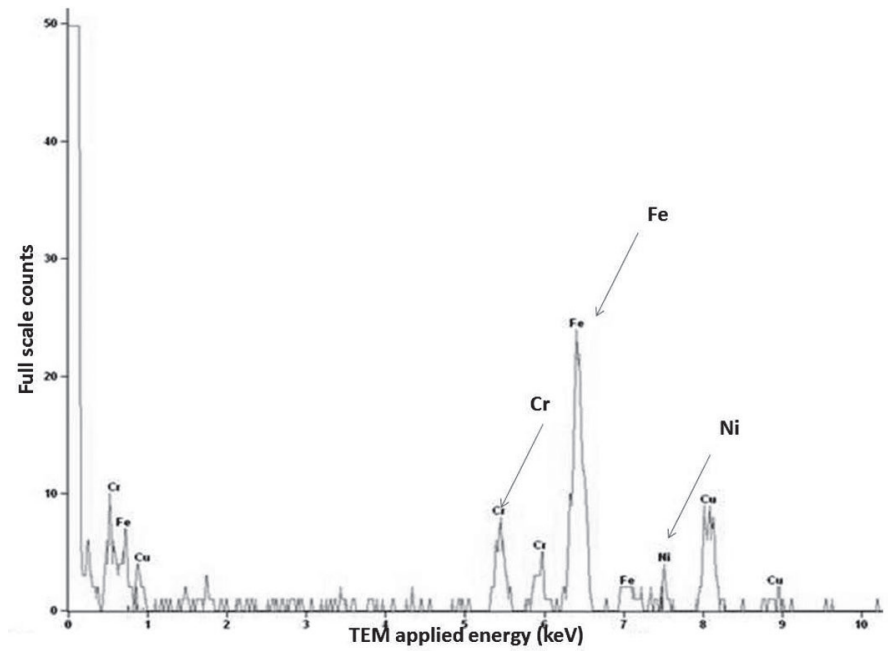

Figure 14. EDS spectra showing chemical composition of nanoparticles collected for welding with $91 \% \mathrm{Ar}+5 \% \mathrm{He}+2 \% \mathrm{CO}_{2}+2 \% \mathrm{~N}_{2}$ : stainless steel

\section{Conclusions}

From this work the following conclusions can be driven:

i) the emission of ultrafine particles, as measured by ADSA, seems to be related to element volatilization and it gets more voluminous with the increase of welding parameter intensities, such as current and voltage;

ii) regarding the studied metal transfer modes, the spray mode originated higher emissions of nanoparticles, while it is known for usually not showing spatter. However, this mode occurs at very high current intensity and voltage;

iii) the short-circuit mode resulted in lower average ADSA values for all gas mixtures tested;

iv) the globular transfer mode, for the majority of tested conditions, resulted in ADSA values between short-circuit and spray modes;

v) regarding mild steel welding, $\mathrm{Ar}+18 \% \mathrm{CO}_{2}$ resulted in higher ADSA values than $\mathrm{CO}_{2}$, which was unexpected, as previous studies on fume emissions [1] showed that the fume formation increased with the increase of $\mathrm{CO}_{2}$ in the gas mixture;

vi) concerning stainless steel, the ternary mixture of $81 \% \mathrm{Ar}+18 \% \mathrm{He}+1 \% \mathrm{CO}_{2}$ resulted in high $\mathrm{ADSA}$ values, which seems to result from the high quantity of He in the mixture. As He has a high ionization energy compared to Ar, the resulting electric arc has a higher temperature and is larger, producing higher volatilization of elements;

vii) comparing the base materials tested, it should be noticed that higher ADSA values were obtained for stainless steel than for mild steel. Also, the emitted nanoparticles for stainless steel showed the presence of nickel and chromium which are potentially carcinogenic elements;

viii) the collected particles, both for mild steel and stainless steel have nanometric dimensions, the majority between 10 and $100 \mathrm{~nm}$, as aggregates. 
This information is quite useful in order to select operating parameters and protection gas mixtures leading to achieve cleaner welding processes.

\section{Acknowledgements}

JG and RM acknowledge the support of Fundación MAPFRE, Madrid, Spain through a Beca I. Hernando de Larramendi. RM acknowledge Pest OE/EME/UI0667/2011, and PC acknowledge Pest OE/CTM/UI0084/2011 from the Portuguese Fundação para a Ciência e a Tecnologia (FCT-MEC).

\section{References}

[1] PIRES, I., QUINTINO, L., MIRANDA, R. Analysis of the influence of shielding gas mixtures on the gas metal arc welding metal transfer modes and fume formation rate. Materials and Design, 28, 1623-31, 2007.

[2] PIRES, I., QUINTINO, L., MIRANDA, R., GOMES, J. Fume emissions during gas metal arc welding. Toxicology \& Environmental Chemistry, 88, 385-94, 2006.

[3] ASCENÇO, C., GOMES, J., COSME, N., MIRANDA, R. Analysis of welding fumes. Toxicology \& Environmental Chemistry, 87, 345-9, 2005.

[4] GOMES, J., ALBUQUERQUE, P., MIRANDA, R., VIEIRA, $M$. Determination of airborne nanoparticles from welding operations. Journal of Toxicology and Environmental Health, Part A, 75, 747-55, 2012.

[5] BUONANNO, G., MORAWSKA, L., STABILE, L. Exposure to welding particle in automotive plants. Journal of Aerosol Science, 42, 295-304, 2011.

[6] MORONI, B., VITI, C. Grain size, chemistry and structure of fine and ultrafine particles in stainless steel welding fumes, Aerosol Science, 40, 938-949, 2011.

[7] JENKINS, N., EAGER, T. Chemical Analysis of Welding Fume Particles Welding Journal, Supp., 87-93, 2005.

[8] OBERDÖRSTER, G., GELEIN, R., FERIN, J., WEISS, B. Association of particulate air pollution and acute mortality: involvement of ultrafine particles. Inhalation Toxicology, 7, 11124, 1995.

[9] OBERDÖRSTER, G. Pulmonary effects of inhaled ultrafine particles. International Archives of Occupational and Environmental Health, 74, 1-8, 2001.

[10] KREYLING, W., SEMMLER, M., ERBE, F., MAYER, P., TAKENAKA, S., SCHULZ, H., OBERDÖRSTER, G., ZIESENIS, A. Translocation of ultrafine insoluble iridium particles from lung epithelium to extrapulmonary organs is size dependent but very low. Journal of Toxicology and Environmental Health - A, 65, 511-35, 2002.

[11] PHALEN, R. Particle Size-selective sampling for particulate air contaminants, Cincinnati: Ed. J.H. Vincent, ACGIH, 2000.

[12] GOMES, J., ALBUQUERQUE, P., MIRANDA, R., SANTOS, T., VIEIRA, M. Comparison of deposited surface area of airborne ultrafine particles generated from two welding processes. Inhalation Toxicology, 24, 774-81, 2012.

[13] BERLINGER, B., BENKER, N., WEINBRUCH, S., L'VOV, B., EBERT, M., KOCH, W., ELLINGSEN, D., THOMASSEN,
Y. Physicochemical characterization of different welding aerosols. Analytical and Bioanalytical Chemistry. 399, 1773-80, 2009.

[14] EAGER, T., KIM, S. Analysis of metal transfer in gas metal arc welding. Welding Journal, 72, 269-78, 1993.

[15] IORDACHESCU, D., QUINTINO, L. Steps toward a new classification of metal transfer in gas metal arc welding. Journal of Materials Processing Technology, 202, 391-7, 2008.

[16] PIRES, I. Analysis of the influence of shielding gas mixtures on features of MIG/MAG, MSc Thesis in Mechanical Engineering, Lisbon: Technical University of Lisbon, 1996 (in Portuguese).

[17] MENESES, V., GOMES, J., SCOTTI, A. The effect of metal transfer stability (spattering) on fume generation, morphology and composition in short-circuit MAG welding. Journal of Materials Processing Technology, 213, 1388-97, 2014. 